\title{
Surveillance of avian paramyxovirus serotype-1 in migratory waterfowls in Japan between 2011 and 2013
}

\author{
Masaji MASE$^{1,2) *}$ and Katsushi KANEHIRA ${ }^{1)}$ \\ 1)National Institute of Animal Health, 3-1-5 Kannondai, Tsukuba, Ibaraki 305-0856, Japan \\ ${ }^{2)}$ United Graduate School of Veterinary Sciences, Gifu University, 1-1 Yanagido, Gifu 501-1193, Japan
}

(Received 21 October 2014/Accepted 25 November 2014/Published online in J-STAGE 7 December 2014)

ABSTRACT. To further understand the epidemiology of avian paramyxovirus serotype-1 (APMV-1) in migratory waterfowls in Japan, we conducted the surveillance of this virus from feces derived from the migratory waterfowls collected in 41 Japanese prefectures between October 2011 and March 2013. Six APMV-1 viruses were isolated from total 661 samples. All isolates were identified as the avirulent (lentogenic) type on the basis of intracerebral pathogenicity tests. Genetic analysis showed that these viruses possessed the deduced amino acid sequence of ${ }^{112}$ GKQGR-L ${ }^{117}$ or ${ }^{112}$ ERQER-L ${ }^{117}$ at the cleavage site of the F0 protein, which was identical to the motif in the avirulent type. Phylogenetic analysis based on the partial fusion protein gene classified these APMV-1 isolates into 2 major genetic groups. Four isolates were classified as class II genotype I, and they were genetically closely related to strains isolated in Asian countries, including Japan. In contrast, two isolates were classified as class I, and they were genetically closely related to strains mainly isolated in the U.S.A. KEY WORDS: avian paramyxovirus type 1, genotype, phylogeny

doi: 10.1292/jvms.14-0550; J. Vet. Med. Sci. 77(3): 381-385, 2015

Newcastle disease (ND) is prevalent worldwide, and it causes significant clinical and economic losses in the poultry industry. This disease is caused by specific strains of avian paramyxovirus serotype-1 (APMV-1), which belongs to the genus Avulavirus in the family Paramyxoviridae [10]. At present, there are 12 known serotypes of APMV [10], but all Newcastle disease virus (NDV) isolates are APMV-1, and therefore, NDV is synonymous with APMV-1. Furthermore, on the basis of their genome lengths and the nucleotide sequences, APMV-1 isolates have been classified into two major groups (class I and II) [2].

According to a recent definition by the World Organization for Animal Health (OIE), ND is defined as an infection of birds caused by APMV-1 that meets one of the following criteria for virulence: (a) the virus has an intracerebral pathogenicity index (ICPI) in day-old chicks (Gallus gallus) of 0.7 or greater, or (b) multiple basic amino acids have been demonstrated in the virus at the $\mathrm{C}$-terminus of the $\mathrm{F} 2$ protein and phenylalanine at residue 117 , which is the N-terminus of the F1 protein [10]. The term "multiple basic amino acids" refers to at least three arginine or lysine residues between positions 113 and 116. According to this definition, amino acid residues are numbered from the $\mathrm{N}$-terminus of the amino acid sequence deduced from the nucleotide sequence of the F0 gene; thus, 113-116 corresponds to residues located -4 to

*Correspondence to: Mase, M., Viral Disease and Epidemiology Research Division, National Institute of Animal Health, National Agriculture and Food Research Organization (NARO), 3-1-5 Kannondai, Tsukuba, Ibaraki 305-0856, Japan.

e-mail: masema@affrc.go.jp

(C)2015 The Japanese Society of Veterinary Science

This is an open-access article distributed under the terms of the Creative Commons Attribution Non-Commercial No Derivatives (by-nc-nd) License $<$ http://creativecommons.org/licenses/by-nc-nd/3.0/>.
-1 from the cleavage site.

On the basis of the phylogenetic analysis of the abovementioned F glycoprotein genes, the NDV strains isolated in Japan before 2007 can be classified according to 6 genotypes (class II genotypes I-III, VI, VII and VIII) [7, 8]. Among them, genotype VII is the predominant genotype responsible for most ND outbreaks in chickens, and this genotype is also predominant in East Asian countries, including Japan $[6,8,11,14]$. Genetic analysis shows that recent isolates from Japan are very similar to Korean isolates, suggesting that isolates from Japan share an immediate ancestor with the Korean viruses. The highly pathogenic avian influenza viruses of the H5N1 subtype isolated in Japan were also genetically close to those isolated in Korea, which suggests that these viruses were introduced into Japan by migratory waterfowls $[9,16]$. Migratory birds may be similarly involved in the dissemination of APMV-1 in this area.

Therefore, to further understand the epidemiology of APMV-1 in migratory waterfowls in Japan, we conducted the surveillance of this virus from feces derived from the migratory waterfowls collected from 41 Japanese prefectures between June 2011 and March 2013.

The fecal samples (one sample was made by pooling feces from 5 birds, principally) were periodically collected from feral birds, such as mallard, northern pintail and spot-billed duck, in each Japanese prefecture (Table 1). The collected fecal samples were placed in screw-cap tubes and stored at $-80^{\circ} \mathrm{C}$ until virus isolation.

Each collected sample was suspended at a concentration of approximately $10 \%$ in Eagle's minimum essential medium containing antibiotics. The suspension was centrifuged, and the supernatant was inoculated into the allantoic cavities of 9- to 12-day-old specific pathogen- free chicken embryonated eggs. After inoculation, eggs were incubated at $37^{\circ} \mathrm{C}$ for 6 days, unless the embryo died. The inoculated 
Table 1. Numbers of fecal sample collected in 41 Japanese prefectures between October 2011 and March 2013

\begin{tabular}{|c|c|c|c|c|c|c|c|c|c|c|c|c|c|}
\hline \multirow{2}{*}{ Prefecture } & \multicolumn{3}{|c|}{2011} & \multicolumn{6}{|c|}{2012} & \multicolumn{3}{|c|}{2013} & \multirow{2}{*}{ Total } \\
\hline & Oct. & Nov. & Dec. & Jan. & Feb. & Mar. & Oct. & Nov. & Dec. & Jan. & Feb. & Mar. & \\
\hline Hokkaido & 6 & 6 & 6 & 6 & 6 & 6 & 12 & 6 & 3 & 5 & 3 & 5 & 70 \\
\hline Aomori & & & & & 3 & & 3 & & & 1 & & 1 & 8 \\
\hline Iwate & & 3 & & 3 & & 3 & 3 & 3 & & 3 & & 3 & 21 \\
\hline Miyagi & 1 & & 3 & & 3 & & 3 & & 3 & & 3 & & 16 \\
\hline Akita & 1 & & 1 & & 2 & & 1 & & 3 & & 3 & & 11 \\
\hline Yamagata & & $\underline{3}^{*}$ & & & & 3 & 3 & 3 & & 2 & & 3 & 17 \\
\hline Fukushima & & $\overline{3}$ & & & & & & & & & & & 3 \\
\hline Ibaraki & & & & & & 3 & & 6 & & 3 & & 3 & 15 \\
\hline Tochigi & & & 3 & & 3 & & 3 & & 3 & & 3 & & 15 \\
\hline Gunma & & $\underline{1}$ & & & & & & & & & & & 1 \\
\hline Saitama & & & & 3 & & 3 & & & & & & & 6 \\
\hline Chiba & 3 & & 4 & & 3 & & $\underline{3}$ & & 3 & & $\underline{3}$ & & 19 \\
\hline Kanagawa & & & & & & & & & & 3 & & & 3 \\
\hline Niigata & 3 & & 3 & & 3 & & 3 & & 3 & & 3 & & 18 \\
\hline Ishikawa & 2 & & & & 2 & & & & & & & & 4 \\
\hline Yamanashi & & 3 & & & & 3 & 3 & 3 & & 3 & & 3 & 18 \\
\hline Nagano & & 3 & & 3 & & 3 & 3 & 3 & & 3 & & 3 & 21 \\
\hline Gifu & & & & & & & 3 & & 3 & & 3 & & 9 \\
\hline Shizuoka & 3 & & 3 & & 3 & & 3 & & 3 & & 3 & & 18 \\
\hline Aichi & & & & & & & 3 & 3 & & 3 & & 3 & 12 \\
\hline Mie & 3 & & 3 & & 3 & & 3 & & 3 & & 3 & & 18 \\
\hline Shiga & & 3 & & 3 & & $\underline{4}$ & 3 & 3 & & 3 & & 3 & 22 \\
\hline Kyoto & 3 & & & & 3 & & 3 & & 3 & & 3 & & 15 \\
\hline Osaka & & 3 & & & & & 2 & 3 & & 3 & & 3 & 14 \\
\hline Nara & & & & 3 & & & 3 & 3 & & 3 & & & 12 \\
\hline Wakayama & 3 & & 3 & & 3 & & 1 & & 3 & & 3 & & 16 \\
\hline Tottori & 3 & & 3 & & 3 & & 3 & & 3 & & 3 & & 18 \\
\hline Shimane & & & & & & & & 3 & & 3 & & 3 & 9 \\
\hline Okayama & & 3 & & 3 & & 3 & & 3 & & 3 & & & 15 \\
\hline Yamaguchi & 3 & 3 & & 3 & & 3 & & 3 & 3 & 3 & & 3 & 24 \\
\hline Tokushima & 3 & & 3 & & 3 & & 3 & & 3 & & 3 & & 18 \\
\hline Kagawa & & 3 & & 3 & & 3 & & 3 & & 3 & & $\underline{3}$ & 18 \\
\hline Ehime & 3 & & 3 & & 3 & & 3 & & 3 & & 3 & & 18 \\
\hline Kochi & & 3 & & 3 & & 3 & 3 & 3 & & 3 & & 3 & 21 \\
\hline Fukuoka & 3 & & 3 & & 3 & & 3 & & 3 & & 3 & & 18 \\
\hline Saga & & 3 & & 3 & & 3 & & & & & & 3 & 12 \\
\hline Nagasaki & 3 & & 3 & & 3 & & 4 & & 6 & & 6 & & 25 \\
\hline Kumamoto & & 3 & & 3 & & 3 & 3 & 3 & & 3 & & 3 & 21 \\
\hline Miyazaki & & 3 & & 3 & & & & 3 & 3 & 3 & & & 15 \\
\hline Kagoshima & 3 & & 3 & & 3 & & & & 3 & & 3 & & 15 \\
\hline Okinawa & & 1 & & 3 & & & & 3 & & 3 & & 2 & 12 \\
\hline Total & 49 & 50 & 47 & 45 & 55 & 46 & 86 & 60 & 60 & 59 & 54 & 50 & 661 \\
\hline
\end{tabular}

*The samples from which APMV-1 isolated are shown in bold, italic and underlined.

eggs were then chilled to $4^{\circ} \mathrm{C}$, and the allantoic fluids were harvested and tested to assess their hemagglutination activity. For negative samples, 2 allantoic fluids samples were pooled and repassaged in 2 new eggs to confirm negativity. APMV-1 was identified using the conventional hemagglutination inhibition assay with APMV-1 specific antiserum.

In total, 661 samples were collected during the surveillance period (Table 1), and 6 APMV-1 viruses were isolated from these samples (Table 2).

To evaluate the pathogenicity of isolates, the ICPI val- ues were measured in 1-day-old chicks according to the procedure by OIE [10]. The ICPI values of these isolates were $0-0.2$, and they were classified as the lentogenic type (avirulent virus). These values were similar to those of many isolates previously isolated from waterfowls [19].

In the genetic characterization of these isolates, viral RNA was extracted from infected allantoic fluids using a commercial kit (QIAamp Viral RNA Mini Kit, QIAGEN, Valencia, CA, U.S.A.), according to the manufacturer's instructions. After reverse transcription with SuperScript ${ }^{\mathrm{TM}}$ III (Life 
Table 2. APMV-1 isolates in this study

\begin{tabular}{|c|c|c|c|c|c|}
\hline Isolate & Abbreviation & $\begin{array}{c}\text { Collection } \\
\text { date }\end{array}$ & Host & Genotype & $\begin{array}{c}\text { Fusion protein } \\
\text { cleavage site }\end{array}$ \\
\hline APMV-1/duck/Gunma/1/2011 & JP/Gunma-dk/2011 & Nov.13, 2011 & Mallard and Spot-billed duck & $\begin{array}{l}\text { Class II } \\
\text { genotype I }\end{array}$ & ${ }^{112}$ GKQGR-L ${ }^{117}$ \\
\hline APMV-1/duck/Yamagata/2/2011 & JP/Yamagata-dk/2011 & Nov.28, 2011 & Northern Pintail & $\begin{array}{l}\text { Class II } \\
\text { genotype I }\end{array}$ & ${ }^{112}$ GKQGR-L ${ }^{117}$ \\
\hline APMV-1/duck/Shiga/1/2012 & JP/Shiga-dk/2012 & Mar.12, 2012 & Unidentified duck & $\begin{array}{l}\text { Class II } \\
\text { genotype I }\end{array}$ & ${ }^{112}$ GKQGR-L ${ }^{117}$ \\
\hline APMV-1/duck/Chiba/1/2012 & JP/Chiba-dk/2012 & Oct.26, 2012 & $\begin{array}{l}\text { Northern Pintail and } \\
\text { Spot-billed duck }\end{array}$ & Class I & ${ }^{112}$ ERQER-L ${ }^{117}$ \\
\hline APMV-1/duck/Chiba/1/2013 & JP/Chiba-dk/2013 & Feb.13, 2013 & $\begin{array}{l}\text { Northern Pintail and } \\
\text { Spot-billed duck }\end{array}$ & Class I & ${ }^{112}$ ERQER-L ${ }^{117}$ \\
\hline APMV-1/duck/Kagawa/3/2013 & JP/Kagawa-dk/2013 & Mar.19, 2013 & Eurasian Wigeon & $\begin{array}{l}\text { Class II } \\
\text { genotype I }\end{array}$ & ${ }^{112}$ GKQGR-L ${ }^{117}$ \\
\hline
\end{tabular}

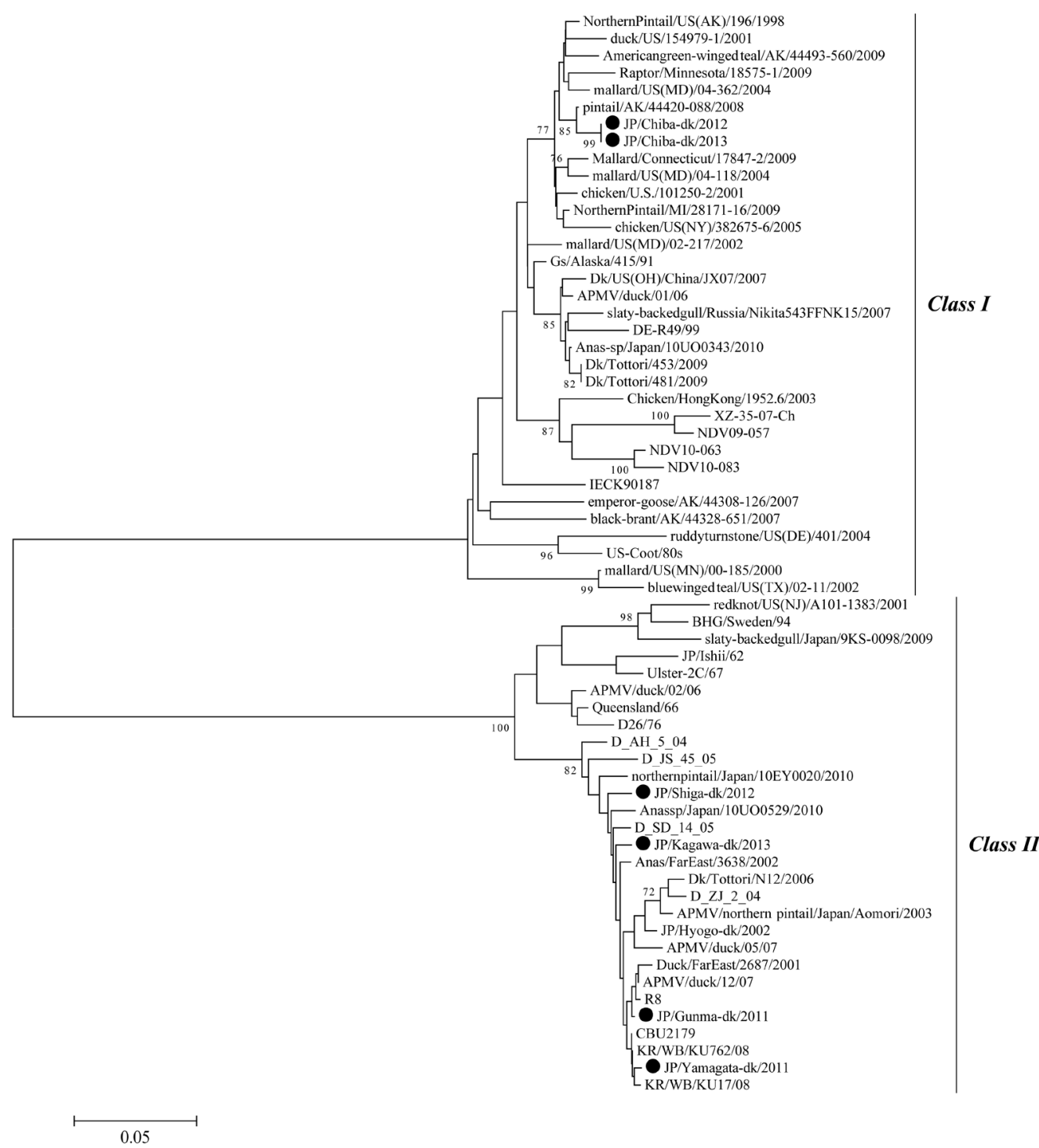

Fig. 1. Phylogenetic tree of the APMV-1 isolates based on nucleotide sequences from a portion (nt 47- 420) of the F gene. The horizontal distances are proportional to the minimum number of nucleotide differences required to join nodes and sequences. The isolates described in this study are shown by black circles. The tree was generated using the neighbor-joining algorithm, and alignments were bootstrapped 1,000 times. Bootstrap values $>70$ are shown. 
Technologies, Gaithersburg, MD, U.S.A.) using random 9- mers, PCR was performed to amplify cDNA with Takara ExTaq (Takara, Tokyo, Japan), which consisted of 35 cycles at $94^{\circ} \mathrm{C}$ for $30 \mathrm{sec}, 50^{\circ} \mathrm{C}$ for $30 \mathrm{sec}$ and $72^{\circ} \mathrm{C}$ for $30 \mathrm{sec}$. The primer sequences and locations were as follows: MSF1 (4306 5' -GACCGCTGACCACGAGGTTA- 3' 4325) and \#2 (5004 5'-AGTCGGAGGATGTTGGCAGC-3' 4985). These sequences were numbered according to a previously published sequence (GenBank Accession. No. AF309418). The sequences amplified by these primers included the $\mathrm{F}$ protein cleavage site and the region used to construct a phylogenetic tree for genotyping the virus, as described previously [1].

DNA fragments with the expected sizes (approximately $700 \mathrm{bp}$ ) were successfully amplified by RT-PCR from all of the APMV-1 samples in this study. The nucleotide sequences obtained were analyzed using GENETYX-Mac (Software Development Corp., Tokyo, Japan). Phylogenetic analysis with available sequences from GenBank was conducted using the Clustal W program, and the tree was constructed by the neighbor-joining method [15] in MEGA6 [18].

The viruses possessed the deduced amino acid sequences of ${ }^{112}$ GKQGR-L ${ }^{117}$ (class II) and ${ }^{112}$ ERQER-L ${ }^{117}$ (class I), respectively, at the cleavage site of the F0 protein, which were identical to motif in the avirulent viruses, and this agreed with the results obtained in the ICPI tests.

Phylogenetic analysis based on the partial fusion protein gene classified these APMV-1 isolates into 2 major genetic groups (Fig. 1). Four isolates were classified as class II genotype I, and they were genetically closely related to strains isolated in Asian countries, including Japan. These class II genotype I viruses have mainly been isolated from feral migratory waterfowl species, including mallard, Baikal teal and northern pintails in the Far East of Asia [5, 13] and North America (U.S.A.) [4].

In contrast, 2 isolates were classified as class I, and they were genetically closely related to strains isolated mainly in the U.S.A. These class I viruses have also been isolated mainly from feral migratory waterfowl species, including mallards and northern pintails in the Far East of Asia [3, 5, 19] and North America [4]. According to analysis using the GenBank BLAST database, the sequences obtained from class I isolates in this study (index isolate: JP/Chiba-dk/2012) were closest to those of the northern pintail/AK/44420088/2008 strain isolated in the U.S.A. (GenBank Accession No. KC503443), where the shared sequence similarity was $98.9 \%$. Two independent groups have recently reported the isolation of class I APMV-1 strains (Dk/Tottori/453/2009 and Anas-sp/Japan/10UO0343/2010) [12, 19]. However, the JP/Chiba-dk/2012 isolate was genetically dissimilar to these isolates compared with the U.S.A. isolates, i.e., shared sequence similarities of only $94.9 \%$ and $95.5 \%$ with the Dk/ Tottori/453/2009 and Anas-sp/Japan/10UO0343/2010 isolates, respectively. These results suggest the possible introduction of genetically diverse class I viruses into Japan, and these viruses have an intercontinental distribution similar to APMV-1 class II genotype I virus [12]. Shengqing et al. previously demonstrated that apathogenic APMV-1 isolate from wild waterfowls in Alaska, which belonged to class I, be- came highly pathogenic after several experimental passages in chickens [17]. Therefore, it is necessary to investigate the potential pathogenicity of isolates, even if they are found to be apathogenic types.

In this surveillance study, the APMV-1 viruses associated with the ND outbreaks in Japan were not isolated, and no pathogenic APMV-1 viruses were isolated. However, the recent isolation of highly pathogenic avian influenza $\mathrm{H} 5 \mathrm{~N} 1$ viruses in Japan that are genetically very similar to Korean isolates $[9,16]$ suggests their possible introduction via migratory waterfowls. For example, the virus strain JP/ Yamagata-dk/2011, which is genetically very similar to the Korean isolate KR/WB/KU17/08 (99.5\% sequence similarity; Fig. 1), was isolated in this surveillance study. Thus, continuous surveillance over many years will be required to further understand the epidemiology of this virus in migratory waterfowls in a similar manner to avian influenza viruses.

ACKNOWLEDGMENTS. This study was supported by a Grant- in- Aid from the Regulatory Research Project (for Food Safety, Animal Health and Plant Protection) of the Ministry of Agriculture, Forestry and Fisheries of Japan. We thank the staff in each prefecture that collected fecal samples. The authors wish to thank Mr. T. Inoue for his technical assistance in this study.

\section{REFERENCES}

1. Aldous, E. W., Mynn, J. K., Banks, J. and Alexander, D. J. 2003. A molecular epidemiological study of avian paramyxovirus type 1 (Newcastle disease virus) isolates by phylogenetic analysis of a partial nucleotide sequence of the fusion protein gene. Avian Pathol. 32: 239-256. [Medline] [CrossRef]

2. Czeglédi, A., Ujvári, D., Somogyi, E., Wehmann, E., Werner, O. and Lomniczi, B. 2006. Third genome size category of avian paramyxovirus serotype 1 (Newcastle disease virus) and evolutionary implications. Virus Res. 120: 36-48. [Medline] [CrossRef]

3. Hu, B., Huang, Y., He, Y., Xu, C., Lu, X., Zhang, W., Meng, B., Yan, S. and Zhang, X. 2010. Avian influenza virus and Newcastle disease virus (NDV) surveillance in commercial breeding farm in China and the characterization of Class I NDV isolates. Vet. Microbiol. 144: 82-86. [Medline] [CrossRef]

4. Kim, L. M., King, D. J., Curry, P. E., Suarez, D. L., Swayne, D. E., Stallknecht, D. E., Slemons, R. D., Pedersen, J. C., Senne, D. A., Winker, K. and Afonso, C. L. 2007. Phylogenetic diversity among low-virulence newcastle disease viruses from waterfowl and shorebirds and comparison of genotype distributions to those of poultry-origin isolates. J. Virol. 81: 12641-12653. [Medline] [CrossRef]

5. Lee, E. K., Jeon, W. J., Kwon, J. H., Yang, C. B. and Choi, K. S. 2009. Molecular epidemiological investigation of Newcastle disease virus from domestic ducks in Korea. Vet. Microbiol. 134: 241-248. [Medline] [CrossRef]

6. Lee, Y. J., Sung, H. W., Choi, J. G., Kim, J. H. and Song, C. S. 2004. Molecular epidemiology of Newcastle disease viruses isolated in South Korea using sequencing of the fusion protein cleavage site region and phylogenetic relationships. Avian Pathol. 33: 482-491. [Medline] [CrossRef]

7. Mase, M., Imai, K., Sanada, Y., Sanada, N., Yuasa, N., Imada, T., 
Tsukamoto, K. and Yamaguchi, S. 2002. Phylogenetic analysis of Newcastle disease virus genotypes isolated in Japan. J. Clin. Microbiol. 40: 3826-3830. [Medline] [CrossRef]

8. Mase, M., Inoue, T. and Imada, T. 2009. Genotyping of Newcastle disease viruses isolated from 2001 to 2007 in Japan. J. Vet. Med. Sci. 71: 1101-1104. [Medline] [CrossRef]

9. Mase, M., Kim, J. H., Lee, Y. J., Tsukamoto, K., Imada, T., Imai, K. and Yamaguchi, S. 2005. Genetic comparison of H5N1 influenza A viruses isolated from chickens in Japan and Korea. Microbiol. Immunol. 49: 871-874. [Medline] [CrossRef]

10. Miller, P. J. and Koch, G. 2013. Newcastle disease. pp. 89-107. In: Diseases of Poultry, 13th ed. (Swayne, D. E., Glisson, J. R., McDougald, L. R., Nolan, L. K., Suarez, D. L. and Nair, V.eds.), Willy-Blackwell, Ames.

11. Qin, Z. M., Tan, L. T., Xu, H. Y., Ma, B. C., Wang, Y. L., Yuan, X. Y. and Liu, W. J. 2008. Pathotypical characterization and molecular epidemiology of Newcastle disease virus isolates from different hosts in China from 1996 to 2005. J. Clin. Microbiol. 46: 601-611. [Medline] [CrossRef]

12. Ramey, A. M., Reeves, A. B., Ogawa, H., Ip, H. S., Imai, K., Bui, V. N., Yamaguchi, E., Silko, N. Y. and Afonso, C. L. 2013. Genetic diversity and mutation of avian paramyxovirus serotype 1 (Newcastle disease virus) in wild birds and evidence for intercontinental spread. Arch. Virol. 158: 2495-2503. [Medline] [CrossRef]

13. Ruenphet, S., Jahangir, A., Shoham, D., Morikawa, K., Miyoshi, Y., Hanawa, E., Okamura, M., Nakamura, M. and Takehara, K. 2011. Surveillance and characterization of Newcastle disease viruses isolated from northern pintail (Anas acuta) in Japan during
2006-09. Avian Dis. 55: 230-235. [Medline] [CrossRef]

14. Rui, Z., Juan, P., Jingliang, S., Jixun, Z., Xiaoting, W., Shouping, Z., Xiaojiao, L. and Guozhong, Z. 2010. Phylogenetic characterization of Newcastle disease virus isolated in the mainland of China during 2001-2009. Vet. Microbiol. 141: 246-257. [Medline] [CrossRef]

15. Saitou, N. and Nei, M. 1987. The neighbor-joining method: a new method for reconstructing pylogenetic trees. Mol. Biol. Evol. 4: 406-425. [Medline]

16. Sakoda, Y., Ito, H., Uchida, Y., Okamatsu, M., Yamamoto, N., Soda, K., Nomura, N., Kuribayashi, S., Shichinohe, S., Sunden, Y., Umemura, T., Usui, T., Ozaki, H., Yamaguchi, T., Murase, T., Ito, T., Saito, T., Takada, A. and Kida, H. 2012. Reintroduction of $\mathrm{H} 5 \mathrm{~N} 1$ highly pathogenic avian influenza virus by migratory water birds, causing poultry outbreaks in the 2010-2011 winter season in Japan. J. Gen. Virol. 93: 541-550. [Medline] [CrossRef]

17. Shengqing, Y., Kishida, N., Ito, H., Kida, H., Otsuki, K., Kawaoka, Y. and Ito, T. 2002. Generation of velogenic Newcastle disease viruses from a nonpathogenic waterfowl isolate by passaging in chickens. Virology 301: 206-211. [Medline] [CrossRef]

18. Tamura, K., Stecher, G., Peterson, D., Filipski, A. and Kumar, S. 2013. MEGA6: Molecular Evolutionary Genetics Analysis version 6.0. Mol. Biol. Evol. 30: 2725-2729. [Medline]

19. Umali, D. V., Ito, H., Katoh, H. and Ito, T. 2014. Surveillance of avian paramyxovirus in migratory waterfowls in the San-in region of western Japan from 2006 to 2012. J. Vet. Med. Sci. 76: 423-430. [Medline] [CrossRef] 